\title{
Sequencing a 903 nucleotide carA gene of Salmonella typhi obtained through PCR employing Ca-3 and Ca-6 primers
}

\author{
Ari Rudiretna ${ }^{1,2}$, A. Saifuddin Noer ${ }^{1,2}$, Sarjono Kisman ${ }^{1,3}$, Oei Ban Liang ${ }^{1,2}$
}

\begin{abstract}
Abstrak
Salmonella typhi adalah bakteri patogen penyebab demam tifoid pada manusia dan informasi mengenai gen yang bertanggung jawab pada patogenitas belum diketahui. Penelitian ini merupakan bagian dari penelitian yang bertujuan utuk isolasi dan karakterisasi gen-gen S. typhi yang spesifik atau diekspresi hanya in vivo untuk pemahaman mekanisme molekuler penyakit demam tifoid, terutama pada tingkat DNA. Gen ivi (in vivo induced) Salmonella typhimurium yang ditemukan dengan cara IVET (in vivo expression technology) yang berperan pada patogenesis penyakit tifoid pada mencit, digunakan untuk identifikasi gen S. typhi yang dimaksud. Makalah ini mendiskusikan sekuens nukleotida S. typhi sebesar 0,9 kb, fragmen hasil amplifikasi PCR menggunakan primer CA-3 dan CA-6. Primer dirancang berdasarkan sekuens nukleotida gen struktural carA dari E. coli K12, dan dipergunakan untuk amplifikasi ekstensi bagian fragmen DNA sebesar 618 bp yang sebelumnya pernah dilaporkan. Fragmen 0,9 kb dianalisa menggunakan ensim restriksi Hinfl dan Sau31 dan diklon ke dalam MosBlue E. coli dengan menggunakan vektor pMosBlue T. Sisipan plasmid rekombinan diisolasi menggunakan ensim restriksi BamHI dan NdeI dan disekuens dengan cara Sanger menggunakan primer universal T7, CA-3, CA-4 dan CA-6. Hasil sekuensing menunjukkan fragmen DNA $0,9 \mathrm{~kb}$ terdiri dari $903 \mathrm{bp}$. Analisa sekuens nukleotida dari fragmen DNA $903 \mathrm{bp}$ ini dan menggabungkannya dengan sekuens dari fragmen 618 bp yang telah dilaporkan, menunjukkan bahwa gen carA yang lengkap dan sebagian kecil gen $\mathrm{car} B$ dari S. typhi telah diuraikan.
\end{abstract}

\begin{abstract}
Salmonella typhi is a pathogenic bacteria that causes typhoid fever in man and information regarding genes responsible for pathogenicity had not been known. This research had been part of a larger design with the objective to isolate and characterize S. typhi genes that are specific or expressed only in vivo. It is principally an effort to understand the molecular mechanism, especially at the DNA level, of the typhoid disease. The ivi (in vivo induced) genes of Salmonella typhimurium, discovered through IVET (In Vivo Expression Technology), that are thought to be intimately related to the pathogenesis mechanism of typhoid like diseases in mice were used in the identification of the intended S. typhi genes. This paper will discuss the nucleotide sequence of a $0.9 \mathrm{~kb}$ S. typhi PCR fragment amplified using CA-3 and CA-6 primers. These primers were designed based on the nucleotide sequence of the structural carA gene of E. coli K12 and can be used to amplify part of the extension of the $618 \mathrm{bp}$ DNA fragment reported before. The $0.9 \mathrm{~kb}$ fragment was analyzed using HinfI and Sau3I restriction enzymes, then cloned into $\mathrm{E}$. coli MosBlue using the pMosBlue T vector. The insert of the recombinant plasmids was isolated using BamHI and NdeI restriction enzymes and sequenced by the dideoxy Sanger method using universal, $T 7, C A-3$, CA-4 and CA-6 primers. The results of all these sequencing experiments had shown without any doubt, that the insert - the $0.9 \mathrm{~kb} \mathrm{~S}$. typhi DNA fragment - consisted of $903 \mathrm{bp}$. Analysing the nucleotide sequence of the $903 \mathrm{bp}$ fragment and combining this with the nucleotide sequence of the previously reported $618 \mathrm{bp}$ DNA fragment, revealed that the complete carA gene and a small part of the car $B$ gene of S. typhi had been elucidated.
\end{abstract}

\section{INTRODUCTION}

Typhoid fever is globally very wide spread and is an endemic disease, mostly prevalent in developing countries. The disease is caused by a pathogenic bacteria, Salmonella typhi that enters the human body through food and drink. In Indonesia, the mortality

\footnotetext{
${ }^{1}$ Inter University Research Center on Biotechnology,

${ }^{2}$ Department of Chemistry,

${ }^{3}$ Department of Pharmacy, Institut Teknologi Bandung,

Bandung, Indonesia.
}

rate due to typhoid disease tends to increase, so that it had become a health problem, which need close and serious attention.

Information regarding molecular pathogenesis and response of the bacterial host cell is very essential for efforts to combat the disease through diagnosis, therapy and immunization. Some light had been shed by the development of a technique called IVET ( In Vivo Expression Technology) by Mekalanos et. al., who had discovered the ivi (in vivo induced) genes of Salmonella typhimurium which are induced and expressed only in the host cell in mice. These genes are thought to be intimately related to the pathogenesis 
mechanism of typhoid-like diseases in mice, and were used in the identification of the intended $S$. typhi genes.

This research had been part of a larger design with the objective to isolate and characterize $S$. typhi genes that are specific or expressed only in vivo. It is principally an effort to understand the molecular mechanism, especially at the DNA level, of typhoid disease through the recombinant DNA and PCR technologies approach.

$0.6 \mathrm{~kb}$ PCR amplified fragments of $S$. typhi, $S$. typhimurium, and $E$. coli $\mathrm{K} 12$ had been obtained using CA-1/CA-2 primers; these fragments were then sequenced. Analysis of the nucleotide sequences of the $S$. typhi fragment showed a similar sequence to the upstream region of the carA gene of $S$. typhimurium LT2. Some nucleotide differences in the sequences were noticed 1,2 .

Attempts had been successfully made to isolate the complete carA genes of $S$. typhi and S. typhimurium in order to obtain information related to the degree of homology between the two carA genes and between these two genes and the carA gene of $E$. coli $\mathrm{K} 12$. For this purpose, CA3/CA- 6 primers were constructed and used for PCR amplification of those carA genes, resulting in $0.9 \mathrm{~kb}$ DNA fragments. The $0.9 \mathrm{~kb}$ DNA fragment of $S$. typhi was proven to be an extension of the $0.6 \mathrm{~kb}$ fragment obtained earlier from $\mathrm{PCR}$ with $\mathrm{CA}-1 / \mathrm{CA}-2$ primers.

\section{METHODOLOGY}

This research consists of the following five steps, namely: designing the primers that will be used in a PCR process; amplifications of the $0.9 \mathrm{~kb}$ DNA fragment of $S$. typhi; restriction analyses of the DNA fragment using Sau3AI and Hinfl restriction enzymes; cloning the DNA fragment using the pMosBlue $\mathrm{T}$ vector with the $E$. coli MosBlue host. The plasmids of several white recombinant clones were then subjected to restriction analyses using BamHI and NdeI enzymes and sequencing of the insert of recombinant plasmids of $S$. typhi were also carried out.

\section{Designing the primers}

The CA-3/CA- 6 primers that were used for the PCR process, were designed based on the nucleotide sequence of the conserved area of the carA and part of the carB structural genes, which form part of the car $\mathrm{AB}$ operon of $E$. coli $\mathrm{K} 12$. The construction of primers were carried out using the Genmon, the proteolize, and the primer detective computer softwares.

\section{Amplification of the $0.9 \mathrm{~kb}$ DNA fragment of $S$. typhi}

The chromosomal DNA template that was used in the PCR process was obtained by lysis of a single colony of the culture of $S$. typhi using a lysis buffer ${ }^{3}$.

The reaction of the PCR process had a total volume of $50 \mu \mathrm{l}$ and consisted of $1 \mathrm{x}$ PCR buffer (Pharmacia), $200 \mu \mathrm{M}$ of dNTP mixture, $10 \mu \mathrm{l}$ of DNA template, and 20 pmol each of the primers. The amplification reaction was carried out in 30 cyles of denaturation at $94^{\circ} \mathrm{C}$ for 60 seconds, annealing at the various temperatures $\left(50^{\circ} \mathrm{C}, 52^{\circ} \mathrm{C}, 53^{\circ} \mathrm{C}, 54^{\circ} \mathrm{C}\right.$, and $55^{\circ} \mathrm{C}$ ) for 60 seconds, and extension at $72^{\circ} \mathrm{C}$ for 60 seconds. For the last cycle, the extension time was four minutes. The PCR product was separated on $2 \%$ agarose gel and stained by ethidium bromide. As DNA marker, DNA fragments of pUC19 cut with HinfI $(1,419 \mathrm{bp}$; $517 \mathrm{bp} ; 397 \mathrm{bp}, 214 \mathrm{bp}$; and $75 \mathrm{bp}$ ) were used.

\section{Restriction analyses of the PCR products}

Restriction analyses were carried out on the $0.9 \mathrm{~kb}$ DNA fragment of $S$. typhi using the $0.9 \mathrm{~kb}$ DNA fragment of $E$. coli $\mathrm{K} 12$ as positive control. Restriction analyses were done with Sau3AI and Hinfl enzymes (Amersham). The restriction fragments were separated on $2 \%$ agarose gel and stained by ethidium bromide. As DNA marker, DNA fragments of pUC19 cut with HinfI were used.

\section{The cloning processes of the $0.9 \mathrm{~kb}$ DNA frag- ments of $S$. typhi}

The $0.9 \mathrm{~kb}$ DNA fragments of $S$. typhi was cloned using pMosBlue $\mathrm{T}$ vector with $E$. coli MosBlue host. The cloning process was carried out according to the procedure that was in the pMosBlue $\mathrm{T}$ kit (Amersham). Several white recombinant clones were taken, followed by the isolation of the plasmids from those clones. The plasmid isolation was done using the minipreparation lysis by alkali method. Those recombinant plasmids were then restriction analysed using $B a m H I$ and NdeI enzymes (Amersham).

\section{Sequencing of the insert of the recombinant plas- mids of $S$. typhi}

The sequencing processes were done using the $\mathrm{T} 7 \mathrm{se}$ quencing kit (Pharmacia) and Thermo Sequenase Radiolabeled Terminator Cycle Sequencing kit (Amer- 
sham). As the primers of the sequencing processes, the universal, $\mathrm{T} 7$ promoter, $\mathrm{CA}-3, \mathrm{CA}-4$, and CA-6 primers were used.

\section{RESULTS AND DISCUSSION}

The computer analysis resulted in a set of a sense primer, termed CA-3 and an antisense primer, termed CA-6. The CA-3 primer has the following DNA sequence: 5' GGCAAAAGAAGT GACCACCGC 3' and the CA-6 primer has the following DNA sequence 5' CAGTGAATCGGCT GATGTAGG 3'.

Using the genomic DNA of $S$. typhi as template, the PCR with the above primers resulted in the amplification of a $0.9 \mathrm{~kb}$ DNA fragment, and the genomic DNA of $E$. coli $\mathrm{K} 12$ was used as a positive control for the PCR process. This $0.9 \mathrm{~kb}$ DNA fragment of $S$. typhi was proven to be an extension of the $0.6 \mathrm{~kb}$ fragment obtained earlier from PCR with CA-1/CA-2 primers. The analyses of the PCR products are shown in Figure 1.

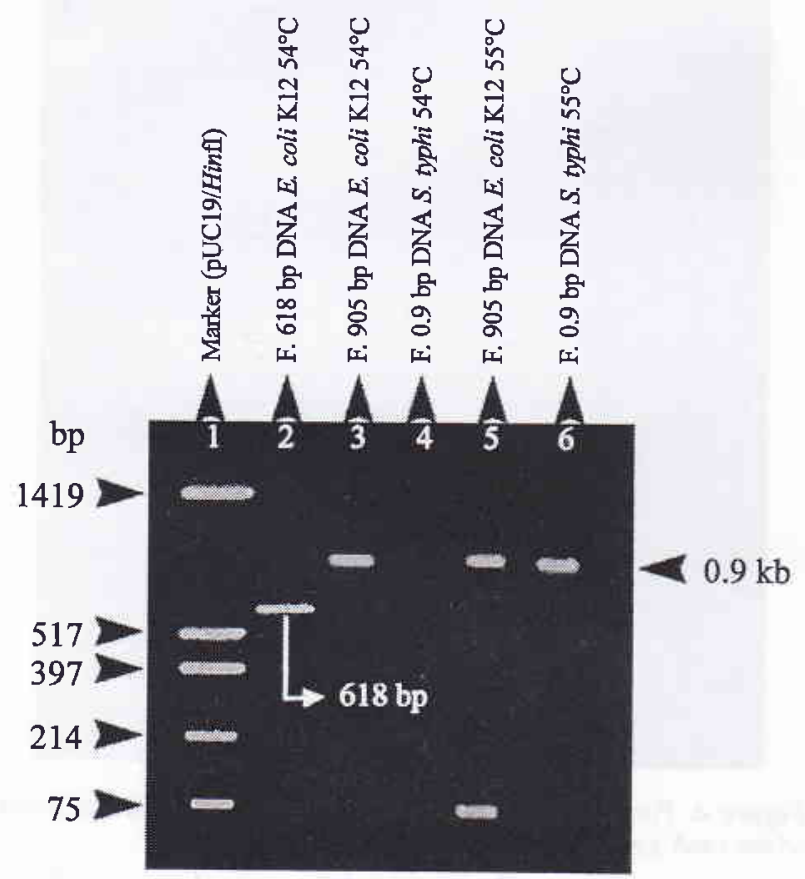

Figure 1. $0.9 \mathrm{~kb}$ PCR Amplified Fragments of S. typhi and E. coli K12.

Line I: DNA marker, the DNA fragments of $p U C 19$ cut with Hinf (1419 bp, $517 \mathrm{bp}, 396 \mathrm{bp}, 214 \mathrm{bp}$ and $75 \mathrm{bp})$; line 2: $0.6 \mathrm{~kb}$ PCR amplified fragment of $\mathrm{E}$. coli $K 12$ using $C A-1 / C A-2$ primers; line 3: $0.9 \mathrm{~kb} P C R$ amplified fragment of $\mathrm{E}$. coli $K 12$ using $C A-3 / C A$ 6 primers, annealing temperature at $54^{\circ} \mathrm{C}$; line $4: 0.9 \mathrm{~kb} P C R$ amplified fragment of $\mathrm{S}$. typhi using $C A-3 / C A-6$ primers, annealing temperature at $54^{\circ} \mathrm{C}$; line 5:0.9 kb PCR amplified fragment of $\mathrm{E}$. coli $K 12$ using $C A-3 / C A-6$ primers, annealing temperature at $55^{\circ} \mathrm{C}$, line $6: 0.9 \mathrm{~kb} P C R$ amplified fragment of $\mathrm{S}$. typhi using $C A-3 / C A-6$ primers, annealing temperature at $55^{\circ} \mathrm{C}$.
According to the literature, the $905 \mathrm{bp}$ DNA fragment of $E$. coli $\mathrm{K} 12$ was known to contain one recognition site of Sau3AI and three recognition site of HinfI. Restriction of this DNA fragment with Sau3AI enzyme would then result in two fragments of $444 \mathrm{bp}$ and 461 bp length. And restriction of this DNA fragment with Hinf I would then result in four fragments of $220 \mathrm{bp}$, $506 \mathrm{bp}, 171 \mathrm{bp}$ and $18 \mathrm{bp}$ length.

Based on the analysis results using gel agarose electrophoresis, restriction analyses of the $0.9 \mathrm{~kb}$ PCR amplified DNA fragment of $E$. coli $\mathrm{K} 12$ using Sau3AI and HinfI enzymes yielded the same theoretically intended fragments. Whereas, restriction analysis of the $0.9 \mathrm{~kb}$ PCR amplified DNA fragment of $S$. typhi using the Sau3AI enzyme gave three fragments of $0.45 \mathrm{~kb}, 0.25 \mathrm{~kb}$ and $0.2 \mathrm{~kb}$ length. Using the Hinf $\mathrm{I}$ enzyme, the $0.9 \mathrm{~kb} S$. typhi DNA fragment gave three fragments of $0.4 \mathrm{~kb}, 0.2 \mathrm{~kb}$, and $0.1 \mathrm{~kb}$ length. The restriction analyses results were shown in Figure 2.

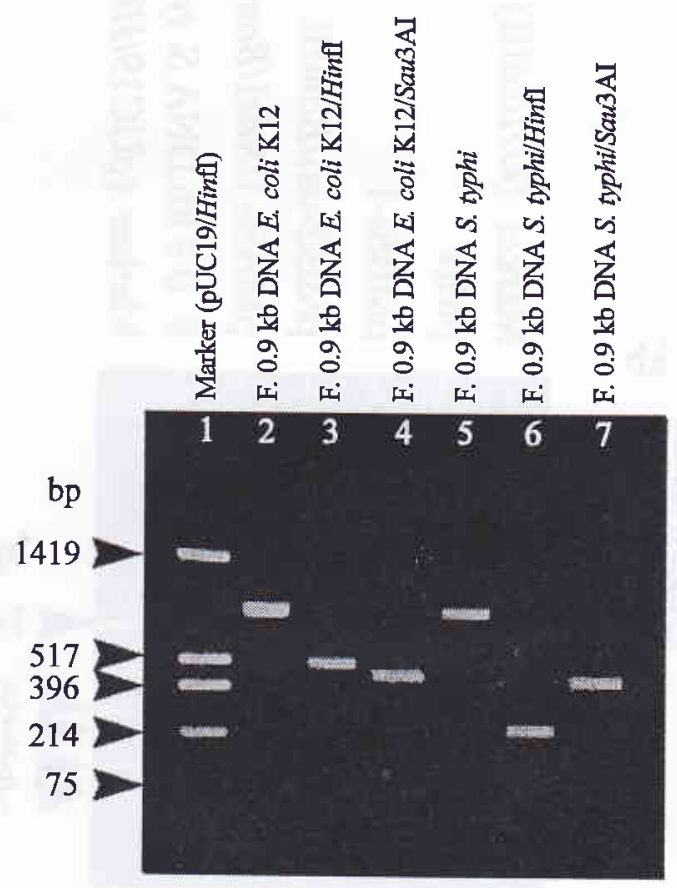

Figure 2. Restriction analyses of $0.9 \mathrm{~kb} P C R$ camplified DNA fragments of S. typhi and $\mathrm{E}$. coli K12 using Sau $3 A$ I and HinfI enzymes.

Line 1: DNA marker, the DNA fragments of pUC19 cut with HinfI (1419 bp, $517 \mathrm{bp}, 396 \mathrm{bp}, 214 \mathrm{bp}$ and $75 \mathrm{bp}$ ); line 2: $0.9 \mathrm{~kb}$ PCR amplified DNA fragment of $\mathrm{E}$. coli $K / 2$, line $3: 0.9 \mathrm{~kb} P C R$ amplified DNA fragment of $\mathrm{E}$. coli $\mathrm{KJ} / 2$ cut with Hinft, line $4: 0.9 \mathrm{~kb}$ $P C R$ amplified DNA fragment of E. coli $K I 2$ cut with Sau $3 A I$. line 5: $0.9 \mathrm{~kb}$ PCR amplified DNA fragment of S. typhi; line 6. $0.9 \mathrm{~kb}$ PCR amplified DNA fragment of S. typhi cut with Hinft, line 7: $0.9 \mathrm{~kb}$ PCR amplified DNA fragment of S. typhi cut with Sau 3 AI 
These restriction fragments of $S$. typhi were found to be different from those of $E$. coli $\mathrm{K} 12$. This is probably due to the difference in position of the recognition site of these enzymes on each of the DNA fragments. This will later on be proven in the nucleotide sequence of the $0.9 \mathrm{~kb}$ DNA fragment of $S$. typhi.

These DNA fragments were then cloned using the pMosBlueT vector and $E$. coli MosBlue host. Several white recombinant clones were obtained. The plasmids of several clones were then subjected to restriction analyses using BamHI and NdeI. This characterisation was carried out to prove that the insert in the recombinant plasmid is the $0.9 \mathrm{~kb}$ DNA fragment of $S$. typhi. These restriction analyses had shown that the the insert of the recombinant plasmids were the intended $0.9 \mathrm{~kb}$ DNA fragment of $S$. typhi. The restriction analyses results are shown in Figure 3.

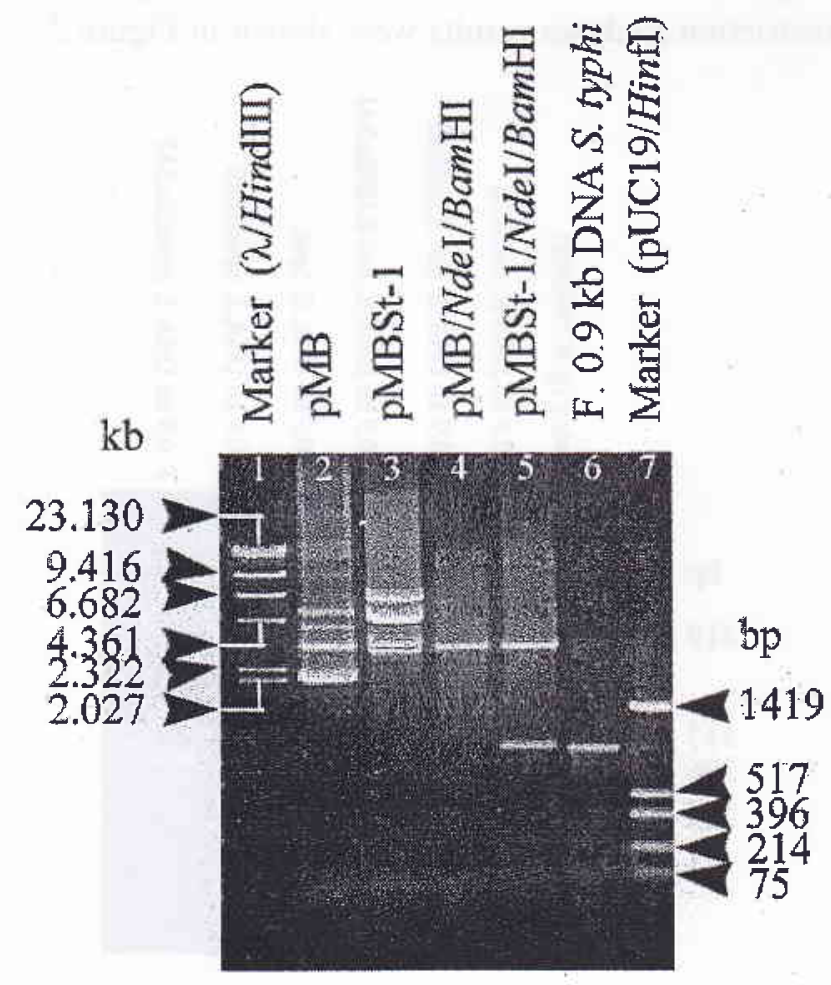

Figure 3. Analysis of S. typhi Recombinant DNA

Line 1: DNA marker, the DNA fragments of the DNA cut with HindIII $(23.130 \mathrm{~kb}, 9.416 \mathrm{~kb}, 6.682 \mathrm{~kb}, 4.361 \mathrm{~kb}, 2.322 \mathrm{~kb}$ and $2.027 \mathrm{~kb}$ ); line 2: E. coli MosBlue recombinant plasmid uncut; line 3: S. typhi recombinant plasmid uncut; line 4: E. coli Mos Blue recombinant plasmid cut with BamHI and NdeI; line 5: S. typhi recombinant plasmid cut with BamHI and NdeI; line 6: 0.9 $k b$ PCR amplified DNA fragment of S. typhi; line 7: DNA marker, the DNA fragments of pUC19 cut with HinfI (1419 bp, $517 \mathrm{bp}$, $396 b p, 214 b p$ and $75 b p)$.
Sequencing of the insert of the $S$. typhi recombinant plasmid (pMB-St1) using universal, T7, CA-3, CA-4, and $\mathrm{CA}-5$ primers had shown, that the inserts were 903 bp DNA fragments. Combining this with the nucleotide sequence of the 618 bp DNA fragment of $S$. typhi that was obtained earlier, the result was the proof of existence of a 1499 bp DNA fragment in $S$. typhi.

This 1499 bp DNA fragment consists of the the car $\mathrm{AB}$ operon promotor, the carA structural gene, the $\operatorname{car} \mathrm{A}-\operatorname{car} \mathrm{B}$ intermediate region and the upstream part of the $\operatorname{car} \mathrm{B}$ structural gene. The nucleotide sequence of the carAB operon promotor and of the carA gene of $S$. typhi had been submitted to and accepted by the GenBank Database with the access number AF012246, 3-July-1997. The part of the autoradiogram that showed the nucleotide sequence of the specific region in the carA gene of $S$. typhi is shown in Figure 4 as an example.

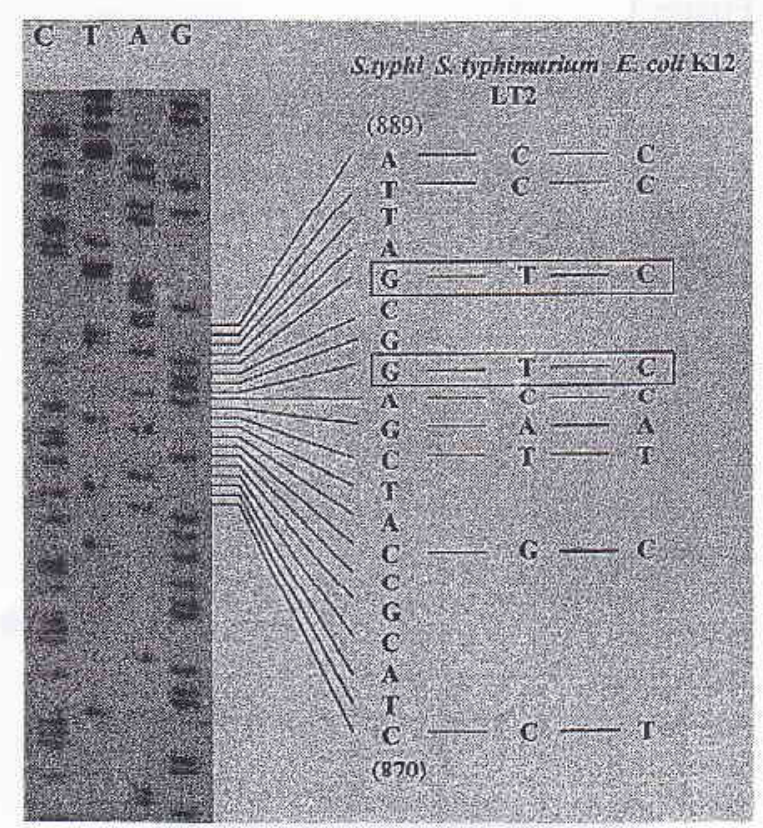

Figure 4. Part of the autoradiogram of the nucleotide sequence of the carA gene of S. typhi.

Nucleotide sequences of corresponding parts of S. typhi, S. typhimurium LT2 (from GenBank) and E. coli KI2 (from GenBank) were shown.

Analysis of the $1499 \mathrm{bp}$ nucleotide sequence resulted in a two tandem promotor that was termed promotor1 (P1) and promotor-2 (P2). P1 starts at base no. 24 and ends at base no. 91 while $\mathrm{P} 2$ starts at base no. 92 and ends at base no. 123. The start codon (TTG) of the carA gene is at base no. $124-126$, and its stop codon (TAA) is at base no. $1270-1272$. The start co- 


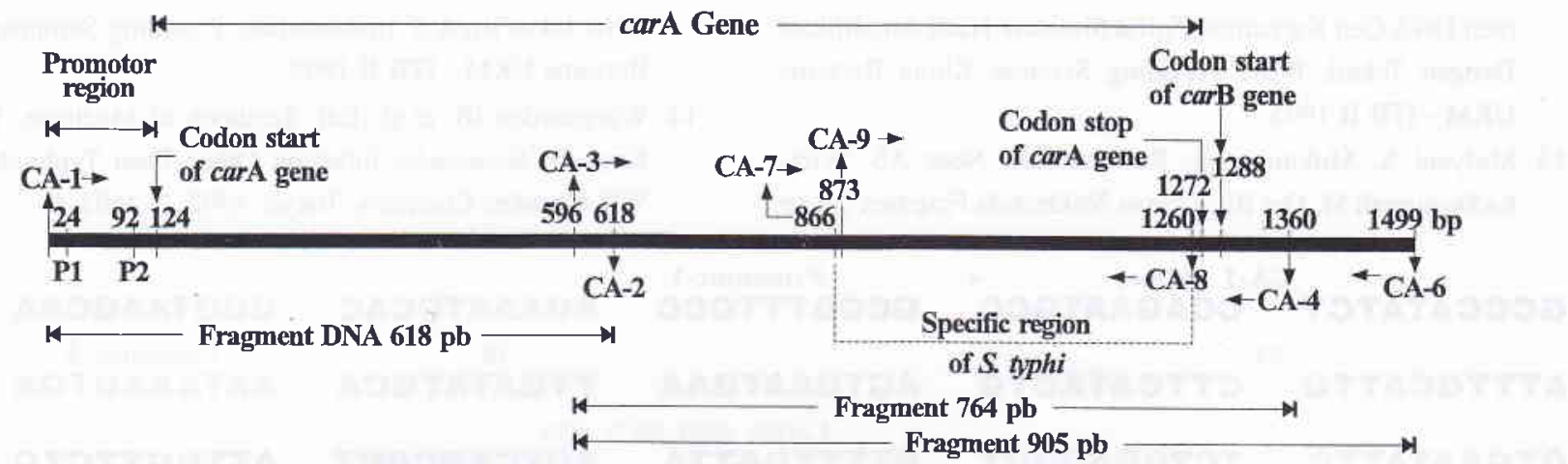

Figure 5. Analysis diagram of the nucleotide sequence of the 1499 bp PCR DNA fragment of S. typhi.

don of the carB gene (ATG) is at base no. 1288-1290. Diagram analysis of the nucleotide sequence of the 1499 bp PCR DNA fragment of $S$. typhi is shown in Figure 5.

\section{CONCLUSIONS}

1. $0.6 \mathrm{~kb}$ and $0.9 \mathrm{~kb}$ DNA fragments of $S$. typhi had been successfully amplified using PCR with CA$1 / \mathrm{CA}-2$ and CA-3 / CA-4 primers. The PCR amplified $0.6 \mathrm{~kb}$ and $0.9 \mathrm{~kb}$ DNA fragments of $S$. typhi had been successfully cloned with the pMosblue $\mathrm{T}$ vector and $E$. coli MosBlue host.

2. The recombinant plasmids of the recombinant clones were subsequently subjected to restriction analyses using HindIII and EcoRI for the $0.6 \mathrm{~kb}$ clone and BamHI and NdeI for the $0.9 \mathrm{~kb}$ clone. The analyses had shown that the inserts of the recombinant plasmids were the intended $0.6 \mathrm{~kb}$ and $0.9 \mathrm{~kb}$ DNA fragments.

3. Sequencing of the inserts of the recombinant plasmids were carried out by the dideoxy Sanger method, and showed that the inserts were a $618 \mathrm{bp}$ and 903 bp DNA fragment respectively.

4. Analysis of the nucleotide sequences of these two DNA fragments and combination thereof resulted in a 1499 bp. DNA fragment consisting of a 123 bp carAB operon promotor, a 1149 bp carA structural gene, a 15 bp carA-carB intermediate region, and a $212 \mathrm{bp}$ upstream part of the carB structural gene.

5. Further analysis of the 1499 bp DNA fragment in relation to the restriction analyses previously carried out on the 618 bp and 903 bp DNA fragments using EcoRV, ClaI, Sau3AI, and HinfI restriction enzymes, is in agreement with the known restriction sites starting at : bp no. 459 for EcoRV, bp no. 461 for ClaI, bp no. 256, 370, 754, and 1041 for Sau3AI, and bp no. 330, 363, 816, 1078, 1320, and 1491 for HinfI.

\section{REFERENCES}

1. Rudiretna A, Noer AS, Kisman S, Oei BL. Amplification And Sequencing of a $0.6 \mathrm{~kb}$ Salmonella typhi DNA Fragment Employing CA-1 and CA-2 Primer. Proceeding Indonesian Biotechnology Conference (In Press) 1997.

2. Noer AS, Rudiretna A, Kisman S, Oei BL. Studi Homologi Fragmen DNA 618 pasang basa gen carA Eschericia coli, Salmonella typhimurium, dan Salmonella typhi. Prosiding Seminar Kimia Bersama UKM - ITB III (In Press) 1997.

3. Noer AS, Martasih F, Mulyani S, Muktiningsih, Wirahadikusumah M. Analisis Variasi Urutan Nukleotida D-Loop MtDNA Manusia Dari Beberapa Daerah Di Indonesia. Prosiding Seminar Kimia Bersama UKM - ITB I 1994.

4. Cabello F, et.al (Ed): Biology of Salmonella, Plenum press. New York pp 1993; 121-9, 131-9.

5. Clarke JM. Novel Non-Templated Nucleotide Addition Reactions Catalyzed by Procaryotic an Eucaryotic DNA Polymerases Nucl Acids. Res 1988; 16: 9677.

6. Glandsdorff N. Biosynthesis of Arginine and Polyamines. In Neidhardt, F.C. (ed): Escherichia coli and Salmonella typhimurium, Cellular and Molecular Biology, American Society for Microbiology Washington DC, 1987; 1: 321-44.

7. Innis MA, Gelfand H. Optimization of PCR. Innis M.A, et.al.(eds): PCR Protocols. A Guide to Methods And Applications, Academic Press Inc California 1990; 3-12.

8. Heithoff DM, Conner CP, Hanna PC, Julio SM, Hentschel U, Mahan MJ. Bacterial Infection as Assessed by In Vivo Gene Expression. Proc Natl Acad Sci 1997; 94: 934-9.

9. Mahan MJ, Slauch JM, Mekalanos JJ, Selection of Bacterial Virulence Genes That Are Specifically Induced In Host Tissues. Science 1991; 259: 686-8.

10. Matchuk D, Drumm M, Saulino A, Collis FS. Construction of T-vectors, A Rapid and General System for Direct Cloning of Unmodified PCR Products. Nucl Acids Res 1991; 19: 1154.

11. Mekalanos JJ. Environmental Signal Controling Expression of Virulence Determinants in Bacteria. Minireview, J of Bacteriology $1992 ; 174(1): 1-7$

12. Muktiningsih, Mulyani S, Rudiretna A, Noer AS, Wirahadikusumah M, Oei BL. Analisis Hornologi Beberapa Frag- 
men DNA Gen Karbamoil Fosfat Sintetase Hasil Amplifikasi Dengan Teknik PCR. Prosiding Seminar Kimia Bersama UKM - ITB II 1995

13. Mulyani S, Muktiningsih, Rudiretna A, Noer AS, Wirahadikusumah M, Oei BL. Urutan Nukleotida Fragmen 0,6 kb
DNA lokus pyrA S. typhimurium. Prosiding Seminar Kimia Bersama UKM - ITB II 1995.

14. Wyngaarden JB, et al (Ed). Textbook of Medicine, 19th ed, Kaye D, Salmonella Infection Other Than Typhoid Fever. WB Saunders Company, Tokyo. 1992; 2: 1691-4.

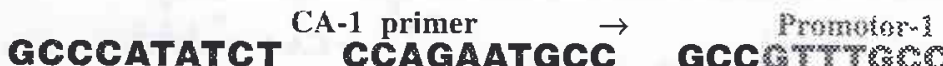

GCCCATATCT CCAGAATGCC

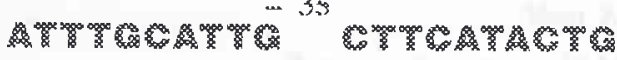

然

GAAGAGGGAA

GGTTGGGGAA

Sark31

TCACT T

GTAATGTCGG

GCAAGGTTTA

ACACCGAAGA

REOKY

ATTGCC

CGCACAGAAC

CGCTGGAAAA

कCCA CCCAGTTTCA GTCGTTTTCA

TCCTATTCCG

caccaatgaa

$$
\operatorname{sinfI}
$$

GT: 1 GC

CCTCTCTTCC

cla

TITCGG GGCTGCATCA

AGCGAAAGCA

CCAAATCGTC

GCCGATGAA TTTCCTGGAC
CA-3 primer $\rightarrow$

$\leftarrow$ cCA-2 primer

AAAGAAGTGA

GCTGAAAGAC

ACGTGGTGGC Saris

GTG GCG

AGAGGTGCTG

GCGACCCGGC

CAGACCGACA

GCTGGCGAGC

CCACCGCGGA

GGTTTACCGG

CTACGATTTT

GCTGCCGCCT

Hivel

AAAAT \&

GCCGTGCGAC

TTCCTGTGTT

GGTGCGAAGA

GCAACCATCC

cagaAccacg

CGTGACCCAC

ACCGACAAAC

CCCGACGATG

CTACCGTTCT

cagatataAa

$\leftarrow$

AGGCGTGTGG

GAAGAACGGT

GGTAAAAGAT

GATTTGCGGT

AAGTCGCTGT

CGGGCGTTCA

CGGCGCCGCT

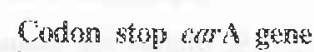

TCAGCAAAA TCAGGAGC Mirefs

AAGCATCCT TTGCCG

ATTTGACTAC ACCCGGGTTA

TCCGGCGCTC TTCTGGTGAA

ATGCCGTT

TTGAGCCTGA

CAAGCTGACC TTGCAGGCGA

AACTTACCGC AAGCGAAATC GGCGCCAAGC

GACGGTGGTG

CGGACGGCAT

TACGCCATCG

CGGCATCTGC

CCGTTAAGAT

GGATGAAG TCGACGGGCA GCTTCCAGGG GTTCGACCAC

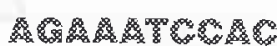
$\xi \xi$

wheng

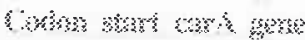

AGTCAGCGCT CGGTCGGGCC ATAGGGGCAA ATACTTCAAT GACCGGTTAT

ACTCTAGCTA

Hingth

\&TTCTC

GATTGCCAGC AACGCCATAA

CGACTGCTGC TAGCCCGGAT TGAACGGTAT

AACTTAAAGG GCGAACGTGG GGATCTGGCA

TGGACGCAGG TGAGGATGAC GCAACATTCT

GTAGCTGGAC CTGCCGTTCC ACGTATGCTG

CCAGCGCAAA

CTTCCTGTCG

AGGCGATTAA

CTCGGCCATC

GAAGTTCGGC

CCTCtGCTGA

AACGGCCCTG

GAAATTCCTC

AACTGCTGGC CATCACGGCG

Sers 3 औ

ACCGCG Hinfl

ACGTGGTGAT

TEGCTGCCCG

CCCTGCAGGG

ACACCCGGGC

TTTATCGAAT

CCAACCTGCG CATTCACCGT GGACGCCGGG TGATTAAGCA

wom

CAACAAA $\%$ CCAAAACGTA

$\stackrel{\leftarrow}{-\quad C A-4}$ primer

GGGCCCGATT GTTATCGGTC

\section{AGGCGTGTAA ACCGGTGCGC} CTCTAACCCG GCCACCATCA $\leftarrow \quad$ cCA-4 primer

ACATCGAGCC Hing

GGTGCCACCT

TGACCGACCC

GGAAATGGCC

Figure 6. The nucleotide sequence of 1499 bp DNA fragment of S.typhi.

Note : The nucleotide sequence of the carA gene of S.typhi had been submitted to and accepted by the GenBank Database with the accesion number AF012246, 3-July-1997. 